\title{
GENRE CHARACTERISTICS OF NEW HISTORICAL POEMS
}

\author{
Dr. Abbos Tursunqulov
}

Senior Lecturer, Jizzakh State Pedagogical Institute, Uzbekistan

\section{ABSTRACT}

The article discusses the genre and artistic features of new historical epics that appeared in the repertoire of folk singers in the early twentieth century. New historical epics are important in terms of defining the creative skills of poets, with the creation of the existing historical reality against the background of stable traditions.

KEYWORDS: - Folklore, art, history, genre, tradition, bakhshi, say, epic.

\section{INTRODUCTION}

New historical epics make up a large part of Uzbek folklore of the 20th century. The author of the new historical epics is clear, the historical changes that have taken place are created on the basis of real events, and it is precisely with this feature that it differs sharply from the traditional epic. But works of this type are created as a creative act within the framework of folklore, more precisely, under the influence of traditional epic style and means of artistic expression.

Therefore, from the point of view of art, in new historical epics, collective populism prevails over individuality, tradition, stability over creative improvisation.

\section{T HE MAIN FINDINGS AND RESULTS}

The realistic character of the new historical epics is an important genre mark of them. Folklorist $\mathrm{T}$. Mirzaev also described historical epics as an important genre, the nature of the description of specific events and facts in history, the level of documentation on the basis of significant differences from each other;

a) historical heroism;

b) historical fiction;

c) historical concrete or new;

d) learns into internal types such as autobiographical epics. We write autobiographical epics with historical-concrete or new epics together we call them new historical epics and study them as an insider. Because there are no genre characters that differ significantly between these subspecies. On the contrary, a number of features are very close to each other in terms of individual creativity, the documentary nature of the events described, the fact that they occurred in 
CURRENT RESEARCH JOURNAL OF PHILOLOGICAL SCIENCES 2(12):

212-215, December 2021

DOI: https://doi.org/10.37547/philological-crjps-02-12-40

ISSN 2767-3758

(C)2021 Master Journals

\section{Crossref doi) 8 Google}

Accepted24th December, 2021 \& Published 29th December, 2021

the folklore of the Soviet era.

New historical epics in terms of historical facts, the way of artistic depiction of real events and the problems of the protagonist can be conditionally divided into two:

1. Works related to the lives of historical figures: Epics of this type, such as "Mamatkarim polvon", "Achil dov", "Komsomolka Aitoti", "Hasan batrak", "Nomaz" have their own prototypes, and the life and work of the hero are told on the basis of real events.

Fozil Yuldosh oglu was personally acquainted with the protagonist of the epic "Mamatkarim polvon" Mamatkarim Jambaylik, a living witness of the events described in the epic "Achil dov", a participant in some places. The heroes of the epic "Hasan batrak" Hasan batrak and Mamarayim sects were the neighbors of the poet Polkan. It is known from historical sources that in the late 19th and early 20th centuries, in the presence of the people's hero Namaz Pirimqul oglu, who fought against the tyranny of local rulers and the tsarist government, the poet Nurmon repeatedly sang epics, praising his work and creating a work called "Prayer". Autobiographical epics of the "My Days" type are related to the past life of a particular bakhshi, and their documentary is guaranteed by the way of life to the bakhshi.

2. Epics related to the historical events. In epics of this type, such as "Jizzakh uprising", "Mardikor", "Heroes of Narpay" of the XX century the movement of the people in their heads is described, and the working people rise to the level of the protagonist. This means that both types of epics are based on what the bakhshis have seen and heard, and documentary is one of the main features of the historical genre.

In the new epics, the current period is depicted against the background of the life and activity of the protagonist without deviating from the historical reality. For this reason, although the documentary plays a leading role in the protagonist's activity, it is typified at the level of the bakhshi's creative skill as an artistic image. In some cases, the leading bakhshis also include in the epic some fictional events that did not take place in real life, but were considered typical for that period. According to Fozil's epic "My Days", the poet was imprisoned for six months for slander. In fact, Fazil bakhshi was not imprisoned. But the life of such poets, who sang the sorrows and dreams of the people, has always existed. For example, Nurman was imprisoned in Kattakurgan for singing about the poet Namaz. The master poet is shot by a punitive squad. Aware of such facts, the poet Fozil pursued an important poetic goal by describing an act that did not exist in his life as "his own." This fact, along with the typification of the image of the bakhshi, corresponds to the historical reality and more fully illuminates the current described period.

Some examples of new historical epics were first called folk songs by folklorist B.Sarimsakov and later by U.Jumanazarov. However, this naming did not lead to strictly identical terms in Uzbek folklore, but rather to diversity. In the scientific literature, works such as "Prayer" are sometimes called historical poems, sometimes historical song. The reason for this is, firstly, that the genre criteria of historical songs are clearly defined and secondly, as B. Sarimsakov said, that some scholars still do not give up naming in the early stages of our folklore. Such works as "Achil dov", "Mamatkarim polvon", "Komsomolka Aitoti", "Mardikor", "Hasan batrak", which depict the reality in a wide epic scale without deviating from the historical reality, combine the features of historical epics, "My days", "Biography" The lack of a certain compositional structure and plot system in the works of the "Jizzakh Uprising" type leads to different opinions about their genre due to the fact that the reality is depicted in a lyroepic direction, rather than on a large scale. They are intermediate forms between the national and the 
CURRENT RESEARCH JOURNAL OF PHILOLOGICAL SCIENCES 2(12):

212-215, December 2021

DOI: https://doi.org/10.37547/philological-crjps-02-12-40

ISSN 2767-3758

(C)2021 Master Journals

\section{Crossref doi) 8 Google}

Accepted24th December, 2021 \& Published 29th December, 2021

historical epic. We support B.Sarimsakov's interesting and serious scientific views on intermediate forms (hybrids) in Uzbek folklore. In addition, to the main theses in the article, we also state some of our comments. Because it would be one-sided to think about the genre features of works of this type without thinking deeply about the factors that led to their emergence in the repertoire of bakhshis. That is why those who call these works historical epics, historical songs, ignore this aspect of the issue and cause different views. In the late nineteenth and early twentieth centuries, the repertoire of folk singers began to appear works in the spirit of oppression and injustice. The works of Nurmon Abduvoy ogli "Namaz", Fozil Yuldosh ogli "Chigirtka”, "Qahatchilik", "Jizzakh uprising" which appeared during this period appeared as a new trend defining the attitude of the bakhshis to the current system. During the period of such events in the early twentieth century, many more works of a new type emerged. There were objective and subjective reasons for this. Because during this period there were talented representatives of several advanced schools of epic poetry, where the tradition of epic poetry is still alive. Second, the period itself was violent and controversial, with a socio-economic formation collapsing and being replaced by a new one. A true people's benefactor, who believed in the triumph of novelty over antiquity, justice over oppression, and truth over violence, would not be left out. For this reason, folk singers appeared not only as performers of traditional epics, but also as singers of the people's pain, progressive propagandists of the time. That is, those who have seen the changes of the new era feel a spiritual need to sing it in comparison to the past. This is first of all reflected in the national creativity, which is a modern and concise genre. However, in order to reflect the dramatic changes and innovations on a larger scale, the team's creativity has narrowed and encouraged the bakhshis to look for relatively more perfect forms.
This creative research has led not only to a renewal of the content of the bakhshis 'repertoire, but also to a change in form. Of course, in addition to the variety of events that were the object of the work, the talents of the bakhshis were also varied. As a result, a number of national and historical epics, as well as works called intermediate forms, emerged. However, it should be noted that the current version of Ergash's biography is only the first part. There are excerpts from the poet Nurmon's epic "Prayer". Since there is no complete version of these works, it means that we have to think about their genre marks depending on the materials available to us.

It is known that Ergash bakhshi was literate and wrote many of his works ("Biography") and submitted them to the folklore archive. In this case, naturally, along with the oral traditions, the peculiarities of the written literature can be mixed, and this process is the basis of the genre of the work affects the improvement of Second, in his biography, the poet Ergash followed the path of the master bakhshis and tried to create a story about his past. Utobiographical works, as T. Mirzaev said: "did not pass directly from teacher to student in the form of the usual repertoire, but his style, the tradition of creating such works. It was natural to be like that. Because in the practice of bakhshis there are many commonalities, but each bakhshi had his own way of life, "his own destiny" in epic poetry. In autobiographical epics, this "own way of life" is described against the background of the period in which he lived. " Third, if we look at the history of Uzbek folklore, the tradition of creating biographical and autobiographical works requires creation only in the genre of national and epic. Undoubtedly, the poet Ergash, who is well aware of this tradition, tried to take advantage of the possibilities of the epic genre, which has a wide epic scope in relation to national creativity, in order to fully cover his past life. The fact that the poet uses a 
CURRENT RESEARCH JOURNAL OF PHILOLOGICAL SCIENCES 2(12):

212-215, December 2021

DOI: https://doi.org/10.37547/philological-crjps-02-12-40

ISSN 2767-3758

(C)2021 Master Journals

crossref do) :810 Google

Accepted24 ${ }^{\text {th }}$ December, 2021 \& Published 29th December, 2021

mixture of prose and poetry of the epic genre in his "Biography" also proves our opinion. But the lack of a wide-ranging, event-rich plot system in the play does not fit into the pattern of the epic genre we are accustomed to. In our opinion, it would be more correct to explain this situation not by the shortcomings of the work, but by the creative pursuit of the bakhshi. In Bakhshi there is a growing desire to sing the new reality in a modern way in a unique way - with a more silent image and uplifting lyrical direction, with a passionate pathos, to tell the story along the way. This case manifested itself as one of the distinctive genre symbols of the new historical epics. He is also evident in the works of the poet Fozil, such as "My Days", "Jizzakh Uprising". But this is not the case with many works created in the later period and called historical epics in the classification of genres. Although some of them grew out of the national genre, they do not meet the requirements of the historical epic genre. Although the works of this type are large in size, they move away from the genre of historical epos with so many features that they should be called terms. Another part is lyro-epic works based on the events of everyday life.

it would be more accurate to add it to the historical song genre features.

\section{Conclusion}

In short, folk singers have made extensive use of epic, folk and song works to reflect the new social reality. As a result of their creative pursuits, intermediate forms also emerged between the national and epic, epic and historical song. The current level of Uzbek folklore studies requires a monographic study of each genre of modern folklore.
1. Mirzaev T. Epic repertoire of folk singers Tashkent, 1979 p.95.

2. Ochilov T., Historical bases of the epic "Mamatkarim polvon", Fozil poet researches, 3 books, 1974, page 75 .

3. Tursunqulova A. The image of the bakhshipoet in historical epics. Literary Heritage, 1983, №4 pp. 54-55.

4. Polkan poet. Research, Book 4, Tashkent., 1976, p.43.

5. Sarimsoqov B. Classification of folk epics and intermediate forms. "Uzbek language and literature", 1981, № 3, 38-47.

6. Jumanazarov U. Historical songs in Uzbek folklore, AKD. Tashkent, 1982.

7. Come on Zarif. Immortal genius. - "Star of the East". № 12. 1968.

8. T.Mirzaev. Epic Repertoire of Folk Singers, p.98.

9. This includes such traditional terms as "My Days", "Is there a world" in the Gorogly language, and such epics as "Oshiq Aydin", "Mulla Ghoib", "Ollonazar Olchinbek" with the image of an ancient bakhshi.

\section{REFERENCES}

